\title{
Wealth Management Strategi Pengelolaan Asset:Transparansi, Akuntabilitas, Efektifitas, Efisiensi
}

\author{
Ainur Rofiq \\ Universitas Islam Negeri Sunan Kalijaga Yogyakarta \\ @mail: ainurrofiq293@yahoo.com
}

\begin{abstract}
Abstrak
Pada umumnya, aset dan kekayaan lembaga sangat penting dan diperlukan untuk memelihara dan mengembangkan kemampuan pendanaan lembaga pendidikan. Uang adalah salah satu dari sumber daya pendidikan yang dianggap sangat penting. Uang diibaratkan seperti darah dalam tubuh manusia. Dan uang adalah termasuk sumber daya yang langka dan terbatas. Oleh karena itu uang perlu dikelola dengan efektif dan efisien agar membantu tercapainya tujuan pendidikan. Pendidikan sebagai investasi yang akan menghasilkan manusia manusia yang memiliki pengetahuan, sikap, dan ketrampilan yang dibutuhkan dalam pembangunan suatu bangsa. Pengelolaan dana pendidikan harus berdasarkan pada prinsip keadilan, efesiensi, transparansi, dan akuntabilitas publik. Transparansi dibidang Wealth management, berarti adanya keterbukaan dalam management keuangan lembaga pendidikan, sedangkan akuntabilitas adalah kondisi seseorang yang dinilai oleh orang lain karena performannya dalam menyelesaikan tugas untuk mencapai tujuan yang menjadi tanggung jawabnya. Dalam management keuangan, dikatakan memenuhi prinsip efektifitas, kalau kegiatan yang dilakukan dapat mengatur keuangan untuk membiayai aktifitas lembaga tertentu dan sesuai dengan rencana yang ditetapkan. Dan efisiensi adalah perbandingan yang terbaik antara masukan dan keluaran, atau antara daya dan hasil.
\end{abstract}

Kata Kunci: Management Keuangan, Transparansi, Akuntabilitas, Efektifitas, Efisiensi 


\section{Wealth Management Strategi Pengelolaan Asset:Transparansi, Akuntabilitas, Efektifitas, Efisiensi}

\section{Pendahuluan}

Istilah wealth management mulai dipakai pada awal tahun 1990, dan mulai familiar di indonesia pada tahun 2000 ketika bank asing yang beroperasi di Indonesia menawarkan jasa wealth management. Wealth management sebagai model yang lebih maju untuk perencanaan keuangan yang memberikan masukan pada individu, keluarga, maupun institusi terkait dengan management asset. Pengelolaan aset kekayaan pada lembaga pendidikan sangat dibutuhkan, karena pada setiap lembaga pasti mempunyai kekayaan dan menginginkan pemeliharaan, penjagaan, dan pengembangan nilai kekayaannya untuk memenuhi kebutuhannya. Dengan demikian, semua jenis organisasi, termasuk organisasi atau lembaga pendidikan islam memerlukan aset dan kekayaan lembaga( asset dan wealth management). ${ }^{1}$

Tidak semua lembaga pendidikan yang menyadari akan pentingnya pengelolaan aset atau kekayaan lembaga. Bahkan banyak lembaga yang tidak mengetahui kekayaan lembagannya. Akibatnya, lembaga tidak mampu secara maksimal mendayagunakan sumber dananya untuk membiayai keperluan lembaganya, dan akhirnya ketergantungan pada penyandang dana,( orang tua siswa, pemerintah, donatur). Sedangkan dana atau keuangan sangatlah vital dalam penyelenggaraan pendidikan dan harus dikelola dengan sebaik mungkin dengan prinsip-prinsip manajemen keuangan dan standar akuntansi. ${ }^{2}$ Wealth management adalah ilmu bagaimana melindungi dan menjaga kekayaan, mengumpulkan dan mengembangkan kekayaan, dan bagaimana mewariskan kekayaan dan menghadapi masa transisi. Definisi ini memberikan masukan akan pentingnya setiap orang membuat perencanaan keuangan sejak semula, pada semua individu, keluarga, maupun organisasi. $^{3}$ Pengelolaan pendidikan dengan wealth management yang baik, yang efektif, efisien, transparan, dan akuntabel harus terus diupayakan sebab pendidikan dengan pengelolaan dapat membawa bangsa bangkit dari keterpurukan dan menjadi investasi di masa yang akan datang. ${ }^{4}$

Dalam Undang Undang No.20/2003 tentang Sistem Pendidikan Nasional pasal 48 menyatakan bahwa pengelolaan dana pendidikan berdasar pada prinsip keadilan, efisiensi,

\footnotetext{
${ }^{1}$ Imam Mahalli dan Ara Hidayat, The Handbook of Education Management, Jakarta: Kecana, 2016, hal 413

${ }^{2}$ Agustinus Herminto, Kepemimpinan Pendidikan Diera Globalisasi, Yokyakarta: Pustaka Pelajar, 2014,hal, 66

${ }^{3}$ https://www.academia.edu/30106656/Pengertian Wealth Management, 06,04,2017

${ }^{4}$ Didin Kurniadin dan Imam Mahalli, Manajemen Pendidikan, Yokyakarta: Ar Ruzz Media,2012, hal 8
} 


\section{Wealth Management Strategi Pengelolaan Asset:Transparansi, Akuntabilitas, Efektifitas, Efisiensi}

transparansi, dan akuntabilitas publik. ${ }^{5}$ Dalam kaitan dengan pengelolaan seluruh sumber dana pendidikan ,termasuk sumber potensi keuangan untuk membiayai penyelenggaraan pendidikan, peran kepala sekolah sangat urgen sebab komponen komponen seperti man,money, dan material tidak akan dapat menjelma berwujud tujuan yang akan dicapai jika tidak di menej oleh seorang pemimpin sekolah yang tangguh. ${ }^{6}$

\section{Pengertian Wealth Management}

Fenomena perebutan dan pencarian siswa pada awal masuk, menunjukkan bahwa sebuah lembaga masih sangat tergantung pada siswa sebagai sumber dana pembiayaan. Pendanaan pendidikan di Indonesia dapat dibedakan menjadi dua bentuk, yang pertama lembaga yang diselenggarakan oleh negara, yang kedua lembaga pendidikan yang diselenggarakan oleh masyarakat dibiayai oleh penyelenggara yang bersangkutan seperti yayasan, perkumpulan, atau badan hukum lain yang sejenis. Dalam definisinnya, Wealth Management is a process of growing, protecting, and managing one's aset through finansial products and services. Wealth Management juga dapat didefinisikan sebagai suatu pendekatan yang komprehensif dalam mengelola produktifitas kekayaan dimana sinergi diperoleh dari perencanaan dan pengembangan yang tepat. Wealth manajemen sangat penting dan diperlukan untuk memelihara dan mengembangkan kemampuan pendanaan lembaga pendidikan. Fenonema pada penerimaan siswa baru juga masih menjadi hal yang utama di SMK Ma'arif Depok, untuk mendapatkan dan mengisi pundi pundi keuangan pendidikan, disamping SMK Ma'arif masih mengandalkan biaya pendaftaraan masuk siswa baru, juga didapat dari pembayaraan SPP tiap bulannya. ${ }^{7}$

Dalam prespektif manajemen, Wealth Management di pandang sangat urgen sekali, sebab sebuah lembaga pendidikan tidak hanya dipandang hanya sebagai sebuah " lembaga" saja, namun juga harus dipandang sebagai sebuah korporat yang memerlukan manajemen secara menyeluruh, meliputi perencanaan, pengorganisasian, pelaksanaan, pengawasan, pengajaran, keuangan, kekayaan, SDM, strategi, pemasaran, pengembangan, dan sebagainnya. ${ }^{8}$

Wealth management adalah suatu proses pengembangan, proteksi, dan pengelolaan, kekayaan seseorang atau organisasi melalui produk dan jasa finansial. Wealth Management juga

\footnotetext{
${ }^{5}$ Muhaimin, Suti'ah, Sugeng listyo Prabowo, Manajemen Pendidikan, Jakarta: Kencana, 2009, hal 201

${ }^{6}$ Dadang Suhardan, Ekonomi dan Pembiayaan Pendidikan, Bandung: Alfabeta, 2012, hal 67

${ }^{7}$ Wawancara dengan Bu Erna Widyastuti, Bendahara SMK Ma'arif Sambego Depok, $19,04,2017$

${ }^{8}$ Imam Mahalli dan Ara Hidayat, The Handbook of Education Management, Jakarta: Prenadamia Group, 2016, hal 414
} 


\section{Wealth Management Strategi Pengelolaan Asset:Transparansi, Akuntabilitas, Efektifitas, Efisiensi}

didefinisikan sebagai suatu pendekatan komprehensif dalam mengelola produktifitas kekayaan di mana sinergi diperoleh dari perencanaan dan pengembangan yang tepat. ${ }^{9}$ Wealth management dapat diklasifikasikan sebagai tipe yang lebih maju dari perencanaan keuangan yang memberikan nasihat untuk individu dan keluarga mengenai perencanaan tanah, managemen aset, perpajakan, dan manajemen portofolio. Berkembangnya wealth management tidak lepas dari bergesernya budaya menabung ke budaya investasi. Pergeseran ini terjadi antara lain karena tingginya tingkat inflasi dibandingkan dengan tingkat pendapatan dari menabung sehingga orang mencari jalan dan cara agar kekayaannya tidak tergerogoti.

Ada yang menyamakan wealth mangement dengan asset management, financial management, atau investment management. Bahkan ada yang menyebutkan bahwa wealth management hanyalah penggunaan istilah baru saja, dan tidak berbeda dengan istilah-istilah yang telah disebutkan. Terlepas dari itu semua, wealth management merupakan kemajuan atau pengembangan dari ketiga bentuk management tersebut dalam arti yang lebih lengkap, lebih komprehensif, dan menciptakan hubungan antara lembaga pemberi jasa dan klien yang jauh lebih intens. Wealth management mempelajari berbagai ilmu tentang bagaimana melindungi dan menjaga kekayaan, dan bagaimana mewariskan kekayaan dan menghadapi masa transisi atau pensiun. Wealth management meliputi investment management, tax management, financial management, dan risk management. ${ }^{10}$ Wealth Management merupakan salah satu substansi manajamen sekolah yang akan turut menentukan berjalannya kegiatan pendidikan di sekolah. Sebagaimana yang terjadi di substansi manajemen pendidikan pada umumnya, kegiatan manajemen keuangan dilakukan melalui proses perencanaan, pengorganisasian, pengarahan, pengkoordinasian, pengawasan atau pengendalian. Beberapa kegiatan manajemen keuangan yaitu memperoleh dan menetapkan sumber-sumber pendanaan, pemanfaatan dana, pelaporan, pemeriksaan dan pertanggung jawaban. Institusi, organisasi, lembaga atau bahkan diri manusia, dan termasuk juga sekolah membutuhkan adanya manajemen.

\section{Wealth Management Dalam Penyelenggaraan Sekolah}

Wealth Management sangat dibutuhkan oleh penyelenggara pendidikan jalur formal yang mencakup pendidikan anak usia dini, pendidikan dasar, pendidikan menengah, dan pendidikan tinggi, khususnya penyelenggara pendidikan dari masyarakat karena terbatasnya dana dan sumber dana yang tersedia. Untuk mengelola kekayaan atau keuangan, sebaiknya berpedoman pada prinsip dan kaidah manajemen keuangan, adalah sebagai berikut:

\footnotetext{
${ }^{9}$ Imam Mahalli dan Ara Hidayat, The Handbook of Education Management, Jakarta: Prenadamia Group, 2016, hal 414

${ }^{10}$ Imam Mahalli dan Ara Hidayat, The Handbook of Education Management, hal 415
} 


\section{Wealth Management Strategi Pengelolaan Asset:Transparansi, Akuntabilitas, Efektifitas, Efisiensi}

a. Perencanaan keuangan atau pembuataan anggaran keuangan tiap tahun.

b. Kebijakan keuangan, mengelola tata keuangan dengan baik.

c. Pencatatan keuangan, pembukuan keuangan atau keluar masuknya keuangan, pencatatan saldo awal dan akhir, dan sebagainnya.

d. Laporan keuangan, yaitu laporan keuangan akhir tahun.

e. Audit laporan keuangan, yang dilakukan akuntan publik. ${ }^{11}$

Adapun tujuan dari manajemen keuangan adalah untuk memperoleh, dan mencari peluang sumber-sumber pendanaan bagi kegiatan sekolah, agar bisa menggunakan dana secara efektif dan tidak melanggar aturan, dan membuat laporan keuangan yang transparan dan akuntabel. Di sinilah peran seorang manager sekolah atau Kepala Sekolah untuk mengelola keuangan dengan sebaik mungkin dengan memperdayakan sumber daya manusia yang ada di lingkungan sekolah melalui kegiatan manajemen keuangan maka kebutuhan pendanaan kegiatan sekolah dapat direncanakan, diupayakan pengadaannya, dibukukan secara transparan, dan digunakan untuk membiayai pelaksanaan program sekolah secara efektif dan efisien. Untuk itu tujuan manajemen keuangan adalah:

a. Meningkatkan efektivitas dan efisiensi penggunaan keuangan sekolah

b. Meningkatkan akuntabilitas dan transparansi keuangan sekolah.

c. Meminimalkan penyalahgunaan anggaran sekolah.

Untuk mencapai tujuan tersebut, maka dibutuhkan kreativitas kepala sekolah dalam menggali sumber-sumber dana, menempatkan bendaharawan yang menguasai dalam pembukuan dan pertanggung-jawaban keuangan serta memanfaatkannya secara benar sesuai peraturan perundangan yang berlaku.n Selanjutnya fungsi manajemen keuangan dalam pendidikan adalah untuk melaksanakan kegiatan agar suatu tujuan tercapai dengan efektif dan efisien. Secara tegas tidak ada rumusan yang sama dan berlaku umum untuk fungsi manajemen. ${ }^{12}$

\section{Prinsip-prinsip Wealth Management/Manajemen Keuangan Pendidikan}

Manajemen keuangan sekolah perlu memperhatikan sejumlah prinsip. Undang-undang No 20 Tahun 2003 pasal 48 menyatakan bahwa pengelolaan dana pendidikan berdasarkan pada prinsip keadilan, efisiensi, transparansi, dan akuntabilitas publik. Disamping itu prinsip

\footnotetext{
${ }^{11}$ Ibid, hal 416

${ }^{12}$ Tim Dosen Administrasi Pendidikan Universitas Pendidikan Indonesia, Manajemen Pendidikan, Bandung: PT Alfabeta, 2009, hal 92
} 


\section{Wealth Management Strategi Pengelolaan Asset:Transparansi, Akuntabilitas, Efektifitas, Efisiensi}

efektivitas juga perlu mendapat penekanan. Berikut ini dibahas masing-masing prinsip tersebut, yaitu transparansi, akuntabilitas, efektivitas, dan efisiensi. ${ }^{13}$ Berikut ini adalah penjabarannya:

\section{Transparansi}

Transparan berarti adanya keterbukaan. Transparan di bidang manajemen berarti adanya keterbukaan dalam mengelola suatu kegiatan. Di lembaga pendidikan, bidang manajemen keuangan yang transparan berarti adanya keterbukaan dalam manajemen keuangan lembaga pendidikan, yaitu keterbukaan sumber keuangan dan jumlahnya, rincian penggunaan, dan pertanggungjawabannya harus jelas sehingga bisa memudahkan pihak-pihak yang berkepentingan untuk mengetahuinya. Transparansi keuangan sangat diperlukan dalam rangka meningkatkan dukungan orangtua, masyarakat dan pemerintah dalam penyelenggaraan seluruh program pendidikan di sekolah. Disamping itu transparansi dapat menciptakan kepercayaan timbal balik antara pemerintah, masyarakat, orang tua siswa dan warga sekolah melalui penyediaan informasi dan menjamin kemudahan di dalam memperoleh informasi yang akurat dan memadai.

Beberapa informasi keuangan yang bebas diketahui oleh semua warga sekolah dan orang tua siswa misalnya rencana anggaran pendapatan dan belanja sekolah (RAPBS) bisa ditempel di papan pengumuman di ruang guru atau di depan ruang tata usaha sehingga bagi siapa saja yang membutuhkan informasi itu dapat dengan mudah mendapatkannya. Orang tua siswa bisa mengetahui berapa jumlah uang yang diterima sekolah dari orang tua siswa dan digunakan untuk apa saja uang itu. Perolehan informasi ini menambah kepercayaan orang tua siswa terhadap sekolah. Perencanaan RAPBS yang diterapkan di SMK Ma'arif, dibuat sebelum tahun ajaran baru. Dalam pelaksanaan transparansi yang diterapkan di SMK Ma'arif Diponegoro Sambego Depok Sleman, Bu Erna Widyastuti selaku Bendahara SMK mengatakan selalu ada transparansi ketika ada rapat bulanan disampaikan/laporan pada Kepala Sekolah dan disaksikan guru-guru yang lain dan kemudian ada laporan per-smester dengan yayasan. Dan ada juga laporan berupa rekapan yang dilaksanakan ketika rapat kerja tahunan. ${ }^{14}$

\section{Akuntabilitas}

Akuntabilitas adalah kondisi seseorang yang dinilai oleh orang lain karena kualitas performansinya dalam menyelesaikan tugas untuk mencapai tujuan yang menjadi tanggung

\footnotetext{
${ }^{13}$ Manahan Tampubolon, Perencanaan dan Keuangan Pendidikan, Jakarta: Mitra Wacana Media, 2015,hal 189

${ }^{14}$ Wawancara dengan Bu Erna Widyastuti, bendahara SMK Ma'arif Diponegoro Depok, $19,04,2017$
} 


\section{Wealth Management Strategi Pengelolaan Asset:Transparansi, Akuntabilitas, Efektifitas, Efisiensi}

jawabnya. Akuntabilitas di dalam manajemen keuangan berarti penggunaan uang sekolah dapat dipertanggungjawabkan sesuai dengan perencanaan yang telah ditetapkan. Berdasarkan perencanaan yang telah ditetapkan dan peraturan yang berlaku maka pihak sekolah membelanjakan uang secara bertanggung jawab. Pertanggungjawaban dapat dilakukan kepada orang tua, masyarakat dan pemerintah. Ada tiga pilar utama yang menjadi prasyarat terbangunnya akuntabilitas, yaitu (1) adanya transparansi para penyelenggara sekolah dengan menerima masukan dan mengikutsertakan berbagai komponen dalam mengelola sekolah , (2) adanya standar kinerja di setiap institusi yang dapat diukur dalam melaksanakan tugas, fungsi dan wewenangnya, (3) adanya partisipasi untuk saling menciptakan suasana kondusif dalam menciptakan pelayanan masyarakat dengan prosedur yang mudah, biaya yang murah dan pelayanan yang cepat.

\section{Efektivitas}

Efektif seringkali diartikan sebagai pencapaian tujuan yang telah ditetapkan. Efektivitas lebih menekankan pada kualitatif outcomes. Manajemen keuangan dikatakan memenuhi prinsip efektivitas kalau kegiatan yang dilakukan dapat mengatur keuangan untuk membiayai aktivitas dalam rangka mencapai tujuan lembaga yang bersangkutan dan kualitatif outcomes-nya sesuai dengan rencana yang telah ditetapkan.

\section{Efisiensi}

Efisiensi adalah perbandingan yang terbaik antara masukan (input) dan keluaran (out put) atau antara daya dan hasil. Daya yang dimaksud meliputi tenaga, pikiran, waktu, biaya. Perbandingan tersebut dapat dilihat dari dua hal:

a. Dilihat dari segi penggunaan waktu, tenaga dan biaya, Kegiatan dapat dikatakan efisien kalau penggunaan waktu, tenaga dan biaya yang sekecil-kecilnya dapat mencapai hasil yang ditetapkan.

b. Dilihat dari segi hasil, Kegiatan dapat dikatakan efisien kalau dengan penggunaan waktu, tenaga dan biaya tertentu memberikan hasil sebanyak-banyaknya baik kuantitas maupun kualitasnya.

Tingkat efisiensi dan efektivitas yang tinggi memungkinkan terselenggaranya pelayanan terhadap masyarakat secara memuaskan dengan menggunakan sumber daya yang tersedia secara optimal dan bertanggung jawab. 


\section{Wealth Management Strategi Pengelolaan Asset:Transparansi, Akuntabilitas, Efektifitas, Efisiensi}

\section{Investasi Dan Wealth Management Di Lembaga Pendidikan Islam}

Investasi dalam kamus besar bahasa indonesia adalah menanamkan uang untuk tujuan memperoleh keuangan. Investasi dalam kacamata ekonomi bisa diartikan sebagai menunda konsumsi saat ini dengan harapan mendapatkan keuntungan dimasa depan atau masa akan datang. Pengembangan kekayaan hanya dapat dilakukan secara efektif dengan cara investasi. Sedangkan perbedaan antara menabung dan investasi adalah bahwa jika menabung menyisakan uang atau pendapatan sekarang untuk dikumpulkan guna mencukupi kebutuhan masa yang akan datang yang belum diketahui atau dapat diperkirakan sebelumnya. Sedangkan berinvestasi adalah menambah kekayaan guna memenuhi keperluan yang akan datang dan meningkatkan kesejahteraan. ${ }^{15}$

Berkaitan dengan investasi, Robert T Kiyosaki dalam bukunya the cashflow quadran memetakan orang dalam hubungannya dengan bekerja untuk mencapai kebebasan keuanganya dalam bentuk 4 kuadran.

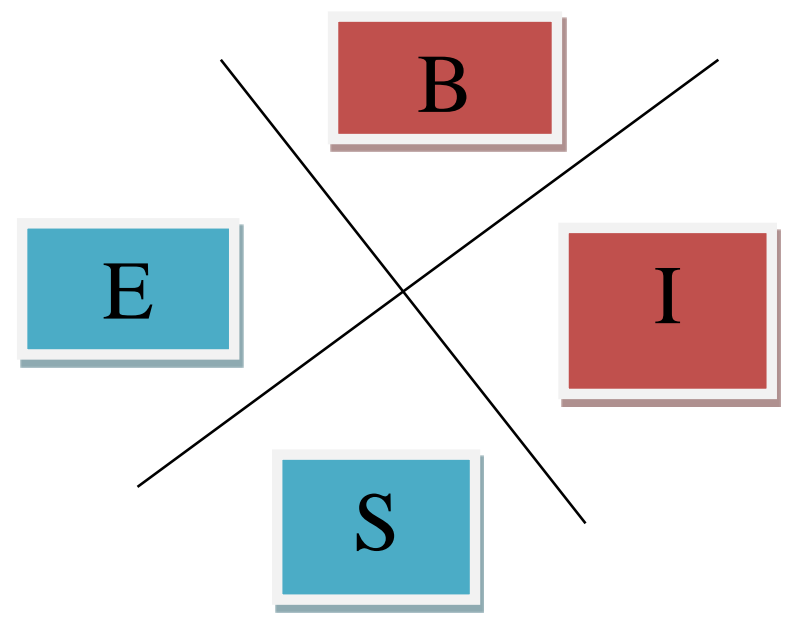

Masing-masing orang kecuali pengangguran, berada dalam salah satu kuadran. Masingmasing kuadran diwakili dengan huruf tertentu, pertama (E) untuk employee/ pegawai yang bekerja untuk orang lain, S untuk self employee/pekerja lepas, B untuk business owner/pemilik usaha, dan I untuk investor / penanam modal. Seseorang dapat berada dalam dua atau lebih kuadran tersebut. Jika satu-satunya sumber pemasukan seseorang adalah gaji, dia berada dikuadran E (employee), jika ia bekerja sendiri dalam usaha sendiri, berada dikuadran S (self

\footnotetext{
${ }^{15}$ Imam Mahalli dan Ara Hidayat, The Handbook of Education Management, Jakarta: Kencana, 2016, hal 416
} 


\section{Wealth Management Strategi Pengelolaan Asset:Transparansi, Akuntabilitas, Efektifitas, Efisiensi}

employee). Kedua jenis ini berada disebelah kiri dari cashflow quadrant. Sedangkan sisi kanan diperuntukkan bagi individu yang melakukan bisnis B ( business owner ) milik mereka, atau melakukan investasi ( I, investor ). Orang-orang pada kelompok E mendapat uang dengan cara bekerja pada orang lain atau bekerja untuk perusahaan. Orang jenis S mendapat uang dengan bekerja untuk diri sendiri. Sedang yang berjenis B mempunyai usaha dan mempekerjakan orang lain dan memperoleh pendapatan berupa keuntungan. Golongan I mendapat uang dari berbagai investasi. Berbagai cara dan metode menghasilkan uang tersebut memerlukan kerangka berfikir, ketrampilan teknis, dan sikap yang berbeda. Pada dasarnya, kiyosaki mengatakan bahwa jika ingin meraih kemenangan financial ( financial freedom ), harus berpindah kuadran. Dari sebelah kiri bawah ( E,S ), ke sebelah kanan atas ( B.I ). Kebanyakan orang berpotensi untuk memperoleh pendapatan dari keempat kuadran. Misalnya seorang dokter yang bekerja dirumah sakit ( E ), namun ia juga bisa membuka praktik sendiri dirumah ( S ), dokter tersebut juga dapat memutuskan untuk membuat medika centre dan mempekerjakan dokter-dokter yang lain. Ia juga memperoleh penghasilan dari kepemilikan saham, obligasi, atau jasa reksadana.

Semua bentuk investasi, seperti investasi tanah, bangunan, real estate, instumen pasar uang, instrumen pasar modal dapat dilakukan oleh lembaga pendidikan. Dana abadi atau endowment adalah sejumlah dana yang diinvestasikan sedemikian rupa sehingga nilai pokoknya tetap tidak disentuh untuk periode waktu tertentu, dimana pendapatan investasinya dapat digunakan untuk kegiatan tertentu. Di Amerika Serikat, pemupukan endowment merupakan hal yang sudah lama dipraktikkan, termasuk dalam penyelenggaraan pendidikan. Diantaranya dengan menerima sumbangan berupa uang, surat berharga, atau tanah yang diberikan donatur perorangan, perusahaan, atau yayasan, alumni, atau perkumpulan alumni.

Dalam penyelenggaraan pendidikan di Indonesia, tradisi pemupukan dana abadi belum menjadi kebiasaan atau kegiatan yang populer. Pemberian dana abadi dari donatur perorangan, perusahaan, atau yayasan belum menjadi tradisi yang berkembang di Indonesia. Yang pasti, pemupukan dana abadi untuk penyelenggaraan pendidikan sangat berguna,

yaitu yang pertama untuk menciptakan sumber pendapatan yang permanen, kedua menstabilkan pendapatan, dan ketiga mengurangi beban biaya yang dipikul oleh peserta didik. ${ }^{16}$

Pendekatan cashflow quadran Robert T kiyosaki dapat digunakan juga dalam melihat lembaga pendidikan. Pengelolaan dan penyelenggaran lembaga pendidikan yang hanya menggantungkan pendapatan dari sumbangan dan SPP siswa yang berada di kuadran (E).

\footnotetext{
${ }^{16}$ Imam mahalli dan Ara Hidayat, The Handbook of Education Management, hal 418
} 


\section{Wealth Management Strategi Pengelolaan Asset:Transparansi, Akuntabilitas, Efektifitas, Efisiensi}

Lembaga pendidikan yang mampu memasarkan barang-barang seperti membuka toko, fotokopy, kantin, koperasi dan lainnya disekolah untuk keperluan lembaga berada dikuadran (S). Lembaga pendidikan yang juga dapat mendirikan suatu perseroan terbatas yang membuka usaha dibidang tertentu, menunjuk direksi dan mempekerjakan orang lain untuk mendapatkan keuntungan guna keperluan lembaga. Berada dikuadran (B). Yayasan juga dapat berinvestasi dengan membeli saham, reksadana, obligasi, dan surat berharga lainnya berada di kuadran (I). Untuk lembaga pendidikan pendekatan cashflow quadrant nya dapat dimodifikasi. Jika untuk memetakan seseorang, cashflow quadrant menggunakan pembagian $\mathrm{E}=$ employee(pegawai), $\mathrm{S}=$ self employee(pekerja lepas), $\mathrm{B}=$ business owner(pemilik usaha), dan I = investor(penanam modal). Namun untuk lembaga pendidikan bentuk modifikasinya adalah dengan menggunakan pendekatan $\mathrm{Sd}=$ student donation, yang sepadan dengan posisi $\mathrm{E}$ (employee), Gd(government donation) yang sepadan dengan $\mathrm{S}$ ( self employee), B (business) yang sepadan dengan B, dan I (invesment) .

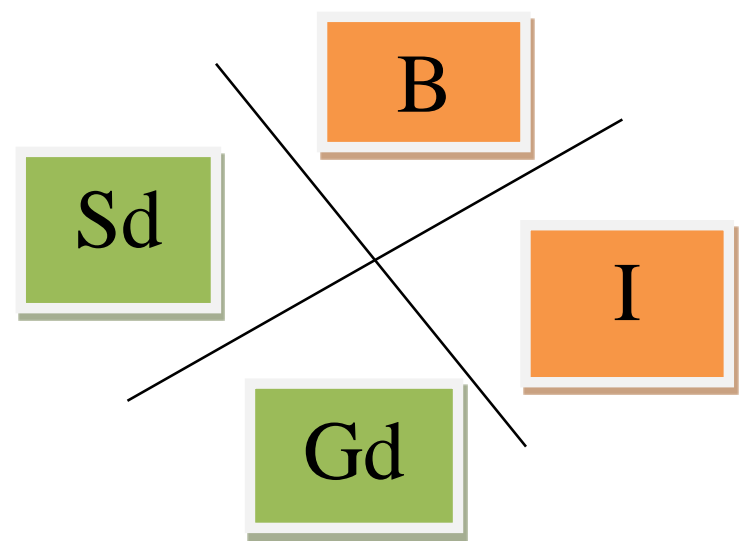

Prinsip-prinsip Wealth Management untuk penyelenggaraan pendidikan sesungguhnya dapat diterapkan di semua jenis lembaga pendidikan atau sekolah yang ada. Pengelolaan uang yang baik, adalah pengelolaan keuangan yang berpedoman pada prinsip-prinsip dan kaidah kaidah manajemen keuangan. Maka untuk itu diperlukan hal sebagai berikut; pertama, perencanaan keuangan; kedua, kebijakan keuangan; ketiga, pencatatan keuangan; keempat, laporan keuangan; kelima, audit laporan keuangan; keenam, analisis atas laporan keuangan. Khusus untuk keperluan wealth management, kebijakan investasi, pengawasan investasi, dan manajemen resiko investasi harus secara jelas dirumuskan dan dilaporkan dalam setiap tahunan 


\section{Wealth Management Strategi Pengelolaan Asset:Transparansi, Akuntabilitas, Efektifitas, Efisiensi}

secara eksplisit. Kebijakan investasi yang perlu dinyatakan dan dilaporkan secara tertulis dan eksplisit diantaranya: pertama; pedoman kebijakan investasi, kedua; jumlah nilai investasi, ketiga; sumber dana investasi, keempat; pedoman kebijakan manajemen resiko, kelima; penentuan jenis resiko yang dihadapi dan cara penanggulangan untuk masing-masing, keenam; penggolongan investasi berdasarkan jenis resiko yang dihadapi, ketujuh; perkembangan nilai dan hasil investasi. Tujuan laporan keuangan adalah menyediakan informasi yang relevan untuk memenuhi kepentingan pemerintah, para donatur, komite, kreditur, dan pihak lain yang menyediakan sumber dana bagi sekolahan/madrasah. Pihak pengguna laporan keuangan memiliki kepentingan bersama dalam rangka menilai. Pertama, aktifitas yang diberikan oleh madrasah dan kemampuannya untuk terus memberikan jasa. Kedua, cara pengurus madrasah melaksanakan tanggung jawabnya dan aspek lain dari kinerja mereka. Pertanyaan yang sering diajukan berkaitan dengan Wealth Management di sekolah apakah suatu yayasan itu boleh melakukan usaha atau ikut dalam kegiatan badan usaha untuk yang mendapatkan keuntungan karena yayasan adalah badan hukum nirlaba.

Pasal 1 butir 1 UU nomor 16 Tahun 2001 jo.UU Nomor 28 tahun 2004 tentang yayasan mencantumkan demikian: yayasan adalah badan hukum yang terdiri atas kekayaan yang dipisahkan dan diperuntukkan untuk mencapai tujuan tertentu dibidang sosial, keagamaan, dan kemanusiaan, yang tidak mempunyai anggota. Pada pasal 3 ayat (1) mengatakan bahwa yayasan dapat melakukan kegiatan usaha untuk menunjang pencapaian maksud dan tujuannya dengan cara mendirikan badan usaha atau ikut serta dalam suatu badan usaha. Pada pasal 3 ayat (1) diatas menjelaskan bahwa yayasan tidak digunakan sebagai wadah usaha dan yayasan tidak dapat melakukan kegiatan usaha langsung, tetapi harus melalui badan usaha yang didirikannya atau melalui badan usaha lain dimana yayasan menyertakan kekayaannya.

Hal ini diperjelas lagi pada pasal 7 ayat 1 dan 2, yang menyatakan bahwa yayasan dapat mendirikan badan usaha yang kegiatannya sesuai dengan maksud dan tujuan yayasan. Hal ini berarti bahwa badan usaha yang didirikan juga harus berhubungan dengan maksud dan tujuan yayasan. Misalnya jika bergerak dibidang pendidikan, yayasan dapat membentuk badan usaha, misalnya perseroan terbatas yang menjual buku pelajaran, peralatan sekolah, dan sejenisnya. ${ }^{17}$ Yayasan tidak boleh mendirikan badan usaha dibidang yang tidak berhubungan dengan kegiatan utamanya. Pada ayat 2 mengatakan bahwa yayasan dapat melakukan penyertaan dalam berbagai bentuk usaha bersifat prospektif dengan ketentuan seluruh penyertaan tersebut paling banyak 25 persen dari seluruh nilai kekayaan yayasan. Artinya, yayasan boleh ikut serta dalam usaha lain,

${ }^{17}$ Opcit, hal 420 


\section{Wealth Management Strategi Pengelolaan Asset:Transparansi, Akuntabilitas, Efektifitas, Efisiensi}

misalnya memiliki saham perseroan terbatas, yang usahanya tidak harus sesuai dengan maksud dan tujuan yayasan, asalkan prospektif, artinya tidak spekulatif, dan dengan nilai penyertaan yang dibatasi. Lembaga pendidikan sebagai sebuah organisasi nirbala yang bertujuan mewujudkan kemandirian dalam penyelenggaraan pendidikan.

\section{Kesimpulan}

Wealth Management atau Manajemen keuangan merupakan salah satu substansi manajamen sekolah yang akan turut menentukan berjalan atau tidaknya kegiatan pendidikan di sekolah. Sebagaimana yang terjadi di substansi manajemen pendidikan pada umumnya, kegiatan manajemen keuangan dilakukan melalui proses perencanaan, pengorganisasian, pengarahan, pengkoordinasian, pengawasan atau pengendalian. Adapun tujuan dari manajemen keuangan adalah untuk memperoleh, dan mencari peluang sumber-sumber pendanaan bagi kegiatan sekolah, agar bisa menggunakan dana secara efektif dan tidak melanggar aturan, dan membuat laporan keuangan yang transparan dan akuntabel.

Ada beberapa prinsip manajemen keuangan pendidkan, yaitu transparansi, akuntabilitas, efektivitas, dan efisiensi. Prinsip-prinsip manajemen tersebut ternyata tidak diterapkan di semua sekolah. Ada beberapa masalah dalam manajemen keuangan pendidkan antara lain: penyalahgunaan keuangan untuk memperkaya diri (korupsi), membebankan pembiayaan kepada siswa didik, pelaporan keuangan yang penuh manipulasi, pembelanjaan keuangan yang tidak tepat guna, dan lain sebagainya. Sedangkan organisasi pendidikan adalah masuk kategori organisasi publik yang nirlaba(non profit). Masalah-masalah tersebut harus mendapatkan perhatian, khsususnya dari pemerintah dan komite sekolah, sehingga tidak menghambat dan merugikan banyak pihak. 


\section{Daftar Pustaka}

Hidayat, Ara, dan Imam Mahalli, 2016, The Handbook of Education Management, Jakarta: Kencana

Kurniadin, Didin dan Mahalli, Imam , 2012, Manajemen Pendidikan, Yokyakarta: Ar Ruzz Media

Muhaimin, Suti'ah, Prabowo, Sugeng listyo, 2009, Manajemen Pendidikan, Jakarta: Kencana

Herminto, Agustinus, 2014, Kepemimpinan Pendidikan Diera Globalisasi, Yokyakarta: Pustaka Pelajar

Suhardan, Dadang , 2012, Ekonomi dan Pembiayaan Pendidikan, Bandung: Alfabeta

Tim Dosen Administrasi Pendidikan Universitas Pendidikan Indonesia, 2009, Manajemen Pendidikan, Bandung: PT Alfabeta

Tampubolon, Manahan, 2015, Perencanaan dan Keuangan Pendidikan, Jakarta: Mitra Wacana Media

https://www.academia.edu/30106656/Pengertian_Wealth_Management, 06,04,2017

Wawancara dengan Bu Erna Widyastuti, Bendahara SMK Ma'arif Diponegoro Depok Sleman Yokyakarta 